\title{
Acute Hyperoxic Injury Attenuates the Relaxing Effects of "Loop" Diuretics and Salbutamol on Large Airways of Newborn Guinea Pigs
}

\author{
G. ANDRE MARINKOVICH, ${ }^{1}$ BRUCE E. PICHOFF, ${ }^{2}$ LYNN M. IWAMOTO, MARSHALL V. C.
} DRESSEL, AND KENNETH T. NAKAMURA

\author{
Departments of Clinical Investigation and Pediatrics, Tripler Army Medical Center, TAMC, Hawaii 96859 \\ [G.A.M, B.E.P., M.V.C.D.] and Department of Pediatrics, John A. Burns School of Medicine Kapiolani \\ Medical Center for Women and Children, Honolulu, Hawaii 96826 [L.M.I., K.T.N.]
}

ABSTRACT

\begin{abstract}
We have previously found an age-dependent relaxing effect of furosemide in normal fetal, newborn, and adult guinea pig airways with fetal trachea exhibiting the greatest relaxation and adult tissue the least. This study was designed to expand upon this finding by determining if in vivo hyperoxic exposure would influence in vitro airway relaxation mediated by the loop diuretics, furosemide and ethacrynic acid, and the $\beta_{2}$-adrenoceptor agonist, salbutamol. Newborn guinea pigs were raised in $>95 \%$ $\mathrm{FiO}_{2}$ until ill; controls in room air. Isometric relaxation to $3 \times$ $10^{-5} \mathrm{M}$ furosemide, $3 \times 10^{-6} \mathrm{M}$ ethacrynic acid, or $10^{-8}-10^{-6}$ $\mathrm{M}$ salbutamol was recorded in $3 \times 10^{-6} \mathrm{M}$ histamine-constricted airway rings. Ethacrynic acid, like furosemide, relaxed newborn
\end{abstract}

Recent evidence suggests that furosemide modulates airway reactivity in vivo. Inhaled furosemide attenuates exercise- (1), allergen- (2), and cold air- $(3,4)$ induced bronchoconstriction in asthmatic adults, and cold air-induced bronchospasm in asthmatic children (5). Furthermore, systemic furosemide decreases airway resistance in infants with bronchopulmonary dysplasia (6-10). Although the mechanisms of furosemide's pulmonary effects have yet to be fully established, most researchers conclude that these effects are unrelated to diuresis. Various mechanisms have been espoused, including inhibition of pulmonary nerves (11), increased pulmonary venous capacitance (12), increased efferent pulmonary lymph flow (13), and

Received August 15, 1994; accepted April 27, 1995.

Correspondence: Kenneth $\uparrow$. Nakamura, M.D., Department of Pediatrics, Kapiolani Medical Center for Women and Children, 1319 Punahou Street, Room 731, Honolulu, HI 96826.

Supported by the U.S. Army Health Services Command; Research Board, Kapiolani Medical Center; University of Hawaii Leahi Trust; and National Institutes of Health Grant HL-45220.

The opinions or assertions contained herein are the private views of the authors and are not to be considered as official or as reflecting the views of the Department of the Army or the Department of Defense.

${ }^{1}$ Present address: $2^{\text {ND }}$ General Hospital, CMR 402, Box 1109, APO AE 09180.

${ }^{2}$ Present address: Department of Pediatrics, William Beaumont Army Medical Center, El Paso, TX 79920. guinea pig airways. Hyperoxia did not alter the contractile effect of $3 \times 10^{-6} \mathrm{M}$ histamine but did significantly decrease the relaxing effect of furosemide, ethacrynic acid, and salbutamol. Loop diuretic mediated airway relaxation was accentuated in HEPES buffer when compared with Krebs, whereas salbutamolmediated relaxation was unaffected. These results suggest that hyperoxia nonspecifically decreases airway responsiveness to the relaxing agents studied. (Pediatr Res 38: 280-285, 1995)

\author{
ORT, optimal resting tension \\ $\mathrm{FiO}_{2}$, fraction of inspired oxygen
}

Abbreviations

increased oncotic pressure leading to decreased efferent pulmonary transcapillary flow $(12,14)$. Stevens et al. (15) found that furosemide directly relaxes normal isolated guinea pig airways, suggesting another possible mechanism.

Furosemide, bumetanide, and ethacrynic acid bind to a $\mathrm{Na}^{+}-\mathrm{K}^{+}-\mathrm{Cl}^{-}$cotransporter in the thick ascending loop of Henle $(16,17)$. This transporter is also functional in other tissues (18). The possible role of this cotransporter in vascular smooth muscle function was first hypothesized by Deth and coworkers (19) who found evidence for a functional $\mathrm{Na}^{+}-\mathrm{K}^{+}$$\mathrm{Cl}^{-}$cotransporter in vascular smooth muscle by demonstrating that: 1) ${ }^{86} \mathrm{Rb}$ uptake (a marker for $\mathrm{K}^{+}$transport) is inhibited by furosemide in the presence of ouabain (to inhibit $\mathrm{Na}-\mathrm{K}$ ATPase) and is $\mathrm{Na}^{+}-, \mathrm{K}^{+}$-, and $\mathrm{Cl}^{-}$- (substrate) dependent; and 2) uptake of ${ }^{45} \mathrm{Ca}$ in rat aorta is reduced by furosemide. They further suggest that HEPES buffer increases basal vascular smooth muscle cotransporter activity in comparison with bicarbonate buffer, based on observations that HEPES buffer increases the furosemide-sensitive portion of ${ }^{86} \mathrm{Rb}$ uptake and accentuates the relaxing effect of furosemide (19). Similar to vascular smooth muscle, we observed accentuation of normal airway relaxation to furosemide in HEPES compared with Krebs buffer (15), suggesting that airway relaxation responses 
in HEPES compared with Krebs buffer may likewise be used to evaluate airway cotransporter activity.

However, patients with normal airways are rarely treated in the clinical setting. Thus, the potential clinical relevance of furosemide mediated airway relaxation must be established in various pathologic conditions, such as hyperoxia-induced airway injury, because hyperoxic exposure increases maximum airway contractility in newborn guinea pigs (20) and immature rats $(21,22)$. On the other hand, little is known about the effects of hyperoxia on airway relaxation. Therefore, this study was designed to answer the questions: 1) Will in vivo hyperoxic exposure influence in vitro airway relaxation caused by furosemide and ethacrynic acid (a structurally different loop diuretic than furosemide)?; 2) Will hyperoxic exposure also affect airway relaxation mediated by the $\beta_{2}$-adrenergic receptor agonist, salbutamol? and 3) Will HEPES buffer selectively accentuate airway relaxation mediated by ethacrynic acid compared with salbutamol?

\section{METHODS}

This study was approved by the Animal Care and Use Committee, Tripler Army Medical Center (TAMC). Procedures on guinea pigs were in accordance with the Guide for the Care and Use of Laboratory Animals (National Institutes of Health Publication No. 85-23, revised 1985) and The Animal Welfare Act and Amendments. TAMC is accredited by the American Association for Accreditation of Laboratory Animal Care.

Series 1. Effect of in vivo hyperoxic exposure on in vitro airway and vascular relaxation by furosemide and ethacrynic acid. One- to 2-d-old newborn guinea pigs (Dunkin Hartley, Charles River Breeding Laboratory, Wilmington, MA) of either sex were raised in hyperoxia as previously described (20) with the following modifications. 1) Oxygen concentration was set at $\geq 95 \% \mathrm{FiO}_{2} ; 2$ ) special care was taken to maintain a high ambient oxygen environment during all animal handling by the use of a small oxygen chamber because rapid transition from a high to normal oxygen milieu can lead to acute morbidity, especially pulmonary edema; and 3) duration of exposure was determined by observation of respiratory distress (tachypnea, retractions, nasal flaring, cyanosis), ruffled fur, and decreased activity. A single investigator (G.A.M.) performed all observations in an attempt to obtain a uniform set of subjects for study, because previous investigators $(21,22,24)$ have described variable pathologic and functional results when exposure time was set $a$ priori. Control animals were matched for age and similarly reared in room air.

Once the hyperoxia-exposed guinea pigs had developed moderate to severe respiratory distress, they were sedated with ketamine $(25 \mathrm{mg} / \mathrm{kg}$ intramuscularly; Vetalar, Parke-Davis, Morris Plains, NJ) and killed with thiopental sodium (250 $\mathrm{mg} / \mathrm{kg}$ intraperitoneally; Pentothal, Abbott Laboratories, Irving, TX). Pleural contents were removed en masse and placed in cold HEPES buffer solution ( $\mathrm{pH}=7.4$ ): $140 \mathrm{mM} \mathrm{NaCl}, 4.5$ $\mathrm{mM} \mathrm{KCl}, 10 \mathrm{mM}$ D-glucose, $1.5 \mathrm{mM} \mathrm{CaCl}-2 \mathrm{H}_{2} 0,1 \mathrm{mM}$ $\mathrm{MgCl}_{2}-6 \mathrm{H}_{2} \mathrm{O}, 5 \mathrm{mM}$ HEPES. HEPES buffer was used because it has been shown to accentuate the relaxing effect of furo- semide on vascular (19) and airway smooth muscle (15). HEPES-filled organ baths were maintained at $37^{\circ} \mathrm{C}$ and bubbled with $100 \% \mathrm{O}_{2}$. The right lung of each animal was used to determine percent lung water (20).

ORT of rings of extrathoracic trachea, mainstem bronchus, aorta, and pulmonary artery were determined as previously described $(15,20,25)$ except that a higher concentration of norepinephrine $\left(6 \times 10^{-6} \mathrm{M}\right)$ was used for vascular tissues. ORT is the tension due to passive stretch at which each ring responds maximally to a constrictor. After setting rings at ORT, an approximate $\mathrm{EC}_{50-70}$ of the physiologic constrictors histamine $\left(3 \times 10^{-6} \mathrm{M}\right)$ and norepinephrine $\left(6 \times 10^{-6} \mathrm{M}\right)$ were used to preconstrict airway and vascular tissues, respectively. Once equilibrium tension, i.e. stable isometric tension after preconstriction, was achieved, $3 \times 10^{-5} \mathrm{M}$ furosemide or $3 \times 10^{-6} \mathrm{M}$ ethacrynic acid was added to each tissue bath, and isometric tension was recorded for $50 \mathrm{~min}$. Time controls were used wherein no diuretic was added. The dose of furosemide was chosen to approximate the serum level achieved in a newborn infant given a $1-\mathrm{mg} / \mathrm{kg}$ i.v. dose of furosemide (15). Preliminary experiments with ethacrynic acid, a more potent diuretic than furosemide, demonstrated quantitatively similar relaxation with a dose equal to $1 / 10$ that of furosemide.

Series 2. Effect of in vivo hyperoxia on in vitro tracheal relaxation by salbutamol. Using a second cohort of guinea pigs, series 1 was repeated to compare salbutamol and ethacrynic acid. Because of the unresponsiveness of vascular tissues to the dose of loop diuretics chosen in series 1 , only tracheal rings were examined in this series. Paired tracheal rings were prepared as described above. Once equilibrium tension to $3 \times 10^{-6} \mathrm{M}$ histamine was achieved, one ring was exposed to cumulative $100-\mu \mathrm{L}$ aliquots of salbutamol, generating a $10^{-8}$ to $10^{-6} \mathrm{M}$ dose-response curve. The second ring was exposed to $3 \times 10^{-6} \mathrm{M}$ ethacrynic acid, and tension was recorded for $50 \mathrm{~min}$.

Series 3. Comparison of ethacrynic acid and salbutamol mediated airway relaxation in HEPES versus Krebs buffer. We reasoned that further indirect evidence to support a $\mathrm{Na}^{+}$$\mathrm{K}^{+}-\mathrm{Cl}^{-}$cotransporter as a mechanism of diuretic action would be provided if HEPES accentuation of airway relaxation was limited to loop diuretics. Thus, from an age-matched cohort of healthy room air-reared guinea pigs, tracheal rings were prepared as described in series 1 except that each extrathoracic trachea was divided as it was removed from the carcass. Paired tracheal rings were mounted in organ baths in either oxygenated HEPES or Krebs $(118 \mathrm{mM} \mathrm{NaCl}, 4.7 \mathrm{mM} \mathrm{KCl}, 11 \mathrm{mM}$ D-glucose, $2.2 \mathrm{mM} \mathrm{CaCl}-2 \mathrm{H}_{2} 0,1.2 \mathrm{mM} \mathrm{MgSO}, 25 \mathrm{mM}$ $\mathrm{NaHCO}_{3}, 1.2 \mathrm{mM} \mathrm{K \textrm {KH } _ { 2 }} \mathrm{PO}_{4}, 0.025 \mathrm{mM} \mathrm{Na} \mathrm{EDTA}_{2}$ ) buffer. Krebs-filled organ baths were maintained at $37^{\circ} \mathrm{C}$ and bubbled with $95 \% \mathrm{O}_{2}-5 \% \quad \mathrm{CO}_{2}$. After determining ORT values and preconstricting tissues with histamine $\left(3 \times 10^{-6} \mathrm{M}\right)$, ethacrynic acid $\left(3 \times 10^{-6} \mathrm{M}, \mathrm{ED}_{\sim 100}\right)$ or salbutamol $\left(10^{-7} \mathrm{M}\right.$, $\mathrm{ED}_{80-100}$ ) was added to each HEPES/Krebs pair, and maximum relaxation was recorded.

Drugs. The following drugs were used: norepinephrine hydrochloride, acetylcholine chloride, atropine, histamine, salbutamol (Sigma Chemical Co., St. Louis, MO); furosemide (Lasix, Hoechst-Roussel Pharmaceuticals Inc., Somerville, 
NJ); ethacrynic acid sodium (Edecrin, Merck Sharp \& Dohme, West Point, PA). Solutions of norepinephrine, acetylcholine, atropine, histamine, and salbutamol were prepared in distilled water on the day of each experiment and kept on ice. Doses were administered in $100-\mu \mathrm{L}$ aliquots to yield drug concentrations which represent final molarity of the $25-\mathrm{mL}$ bath. Furosemide $(2 \mathrm{mg} / 10 \mathrm{~mL})$ was administered as a $25.0-\mu \mathrm{L}$ aliquot to achieve a $3 \times 10^{-5} \mathrm{M}$ bath concentration. Ethacrynic acid was reconstituted with $0.9 \% \mathrm{NaCl}$ as directed by the package insert on the day of the experiment and kept on ice. Ethacrynic acid $(1 \mathrm{mg} / \mathrm{mL}$ ) was administered as a $24.4-\mu \mathrm{L}$ aliquot to achieve a $3 \times 10^{-6} \mathrm{M}$ bath concentration.

Calculations and statistical analysis. Percent lung water was calculated as described by Uyehara et al. (20). Timedependent changes in tension after relaxant administration were calculated as a percentage of equilibrium tension at 5-min intervals, i.e. $[\% \text { change from equilibrium tension }]_{t=n}=$ ([equilibrium tension $]_{t=0}-$ ORT $)-([$ tension after relaxant drug administration $]_{t=n}-$ ORT $) \div(\text { [equilibrium tension }]_{t=0}$ - ORT) $\times 100$; where $n=0,5,10, \ldots, 50$. Time dependent and dose response data were compared by two-way analysis of variance for repeated measures with Duncan's multiple comparison procedure (26). Maximum relaxation attained in the HEPES versus Krebs series was calculated as a percentage of equilibrium tension. Differences between groups of animals were compared using paired or unpaired $t$ tests, as appropriate. Statistical analysis was performed with the software package, SigmaStat (Jandel Sci, San Rafael, CA). $p$ values $<0.05$ were considered significant. All values are expressed as mean \pm SEM.

\section{RESULTS}

Effect of in vivo hyperoxic exposure on in vitro airway and vascular relaxation by furosemide and ethacrynic acid. Animals in series 1 and 2 were killed at approximately $6 \mathrm{~d}$ of age. Characteristics of these animals are listed in Table 1. Animals raised in hyperoxia did not gain weight as well as their room air counterparts $(p<0.05)$. Increases in lung water with hyperoxia are consistent with what we have previously reported (20). Importantly, hyperoxic exposure did not significantly alter the ORT values or active equilibrium tensions in either series 1 or 2 .

Table 1. Effects of hyperoxia exposure on animal characteristics from series 1 and series 2

\begin{tabular}{lcc} 
& Room air & Hyperoxia \\
\hline$N$ & 21 & 30 \\
Weight $(\mathrm{g})$ & $114.7 \pm 3.1$ & $97.3 \pm 2.1^{*}$ \\
Age $(\mathrm{d})$ & $5.2 \pm 0.4$ & $5.7 \pm 0.2$ \\
Lung water $(\%)$ & $79.6 \pm 0.5$ & $84.8 \pm 0.3^{*}$ \\
Trachea $(N)$ & 18 & 28 \\
$\quad$ ORT $(\mathrm{g})$ & $1.78 \pm 0.12$ & $1.62 \pm 0.10$ \\
$\quad$ Equilibrium tension $(\mathrm{g})$ & $2.76 \pm 0.19$ & $3.19 \pm 0.14$ \\
Bronchus $(N)$ & 14 & 18 \\
ORT $(\mathrm{g})$ & $1.46 \pm 0.10$ & $1.47 \pm 0.08$ \\
Equilibrium tension $(\mathrm{g})$ & $1.18 \pm 0.11$ & $1.37 \pm 0.06$ \\
\hline
\end{tabular}

$* p<0.05$ compared to room air controls; $N=$ total number of animals used. Equilibrium tension $=$ the final stable tension reached by an airway ring before relaxant exposure.
Hyperoxic exposure significantly decreased the relaxing ability of furosemide on tracheal and bronchial rings as shown in Figures 1 and 2. Tracheal relaxation response to ethacrynic acid was also decreased in hyperoxia versus normal tissues (Fig. 3) but hyperoxic exposure did not affect bronchial relaxation to ethacrynic acid (Fig. 4). In contrast to airways, identical doses of diuretics did not relax vascular tissues (data not shown).

Effect of in vivo hyperoxia on in vitro tracheal relaxation by salbutamol. The relaxation to $3 \times 10^{-6} \mathrm{M}$ ethacrynic acid was again decreased in tracheal rings from hyperoxic exposed guinea pigs as shown in Figure 5 (right panel). Likewise, airway segments from the same animals concurrently demonstrated a significant decrease in relaxation to cumulative doses of salbutamol (left panel).

Comparison of ethacrynic acid and salbutamol mediated airway relaxation in HEPES versus Krebs buffer. The relaxing effect of furosemide is accentuated by HEPES buffer (15, 19). Figure 6 shows that ethacrynic acid was similarly affected with a significant increase in relaxation in HEPES versus Krebs buffer [HEPES: $111 \pm 10 \%$ versus Krebs: $47 \pm 5 \%(p<$ $0.05)]$. In marked contrast, salbutamol's potency was unchanged by buffer choice [HEPES: $110 \pm 7 \%$ versus Krebs: $102 \pm 6 \%(\mathrm{NS})]$.

\section{DISCUSSION}

Hyperoxia is known to cause pulmonary pathology and dysfunction in many animals $(21-24,27)$, although the mechanism of this injury is not fully understood. Studies examining mechanisms of hyperoxia-induced airway hyperresponsiveness have focused on contractile mechanisms $(20-22,28)$ although excessive airway narrowing could be due to impaired relaxation (29). The most important finding of this study was that in newborn guinea pig airways, in vivo exposure to hyperoxia decreased the relaxing ability of loop diuretics, ethacrynic acid

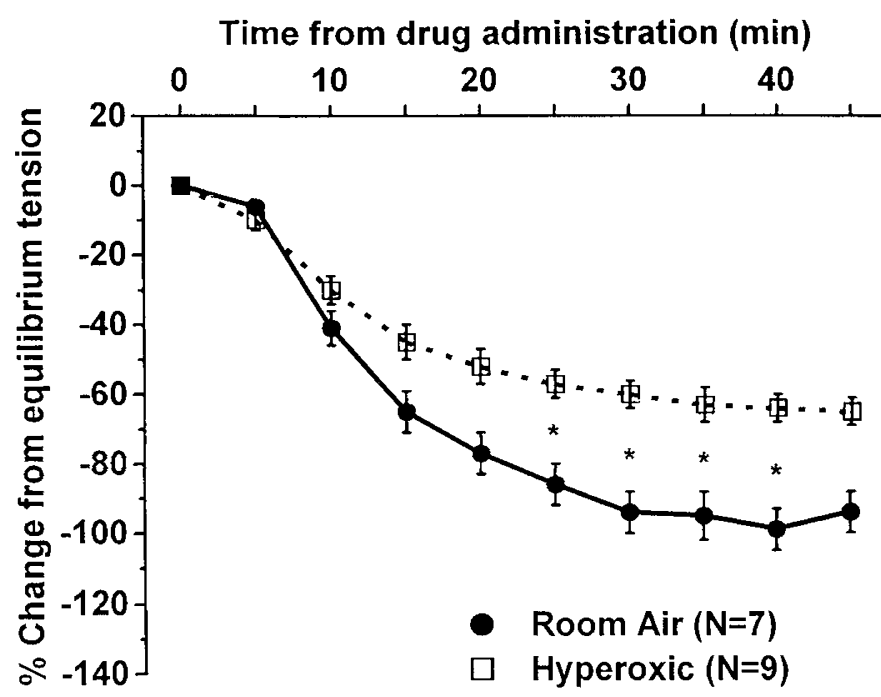

Figure 1. Guinea pig tracheal relaxation to $3 \times 10^{-5} \mathrm{M}$ furosemide. Hyperoxia significantly decreased furosemide's relaxing effect on $3 \times 10^{-6} \mathrm{M}$ histamine preconstricted tracheal rings. $n=$ number of animals. Values are mean \pm SEM. $* p<0.05$ 
Time from drug administration $(\mathrm{min})$

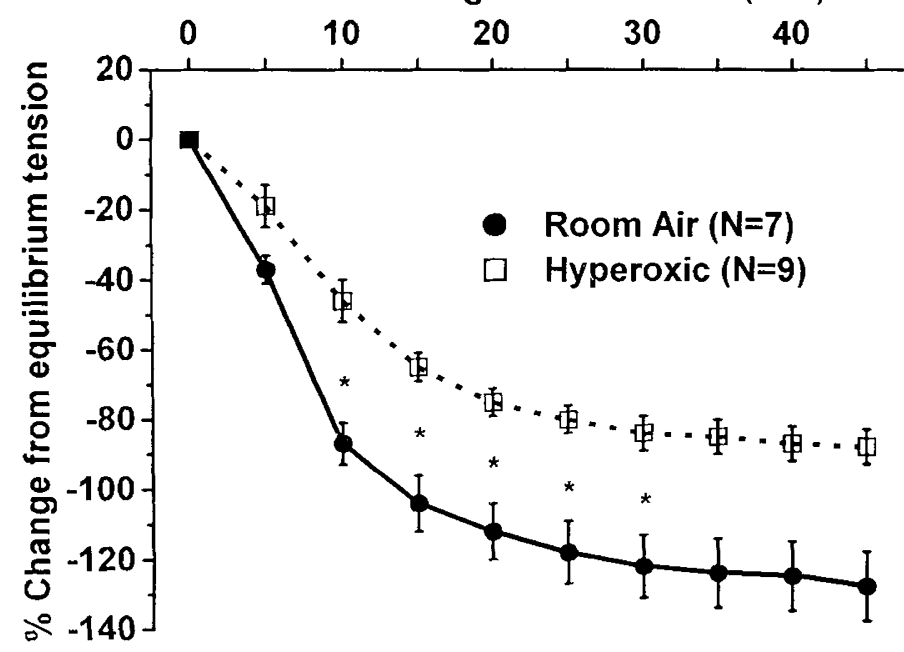

Figure 2. Guinea pig bronchial relaxation to $3 \times 10^{-5} \mathrm{M}$ furosemide. Hyperoxia significantly decreased furosemide's relaxing effect on $3 \times 10^{-6} \mathrm{M}$ histamine preconstricted bronchial rings. $n=$ number of animals. Values are mean \pm SEM. * $p<0.05$.

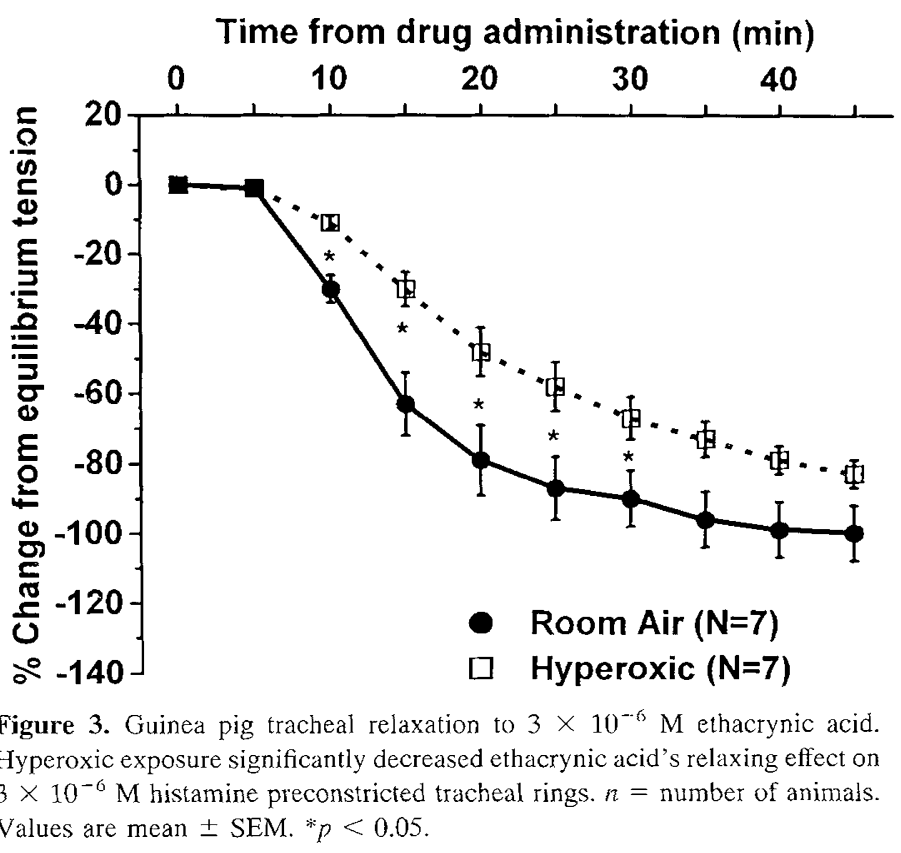

and furosemide, and the $\beta_{2}$-adrenergic receptor agonist salbutamol. The impairment of airway relaxation cannot be explained by differences in induced airway tension because equilibrium tension achieved with an $\mathrm{EC}_{50}$ of histamine before the addition of relaxing drugs was not significantly different (see Table). This is consistent with our previous finding that hyperoxia produces increased maximum airway contractility (efficacy), without affecting sensitivity $\left(\mathrm{EC}_{50}\right)$ to histamine (20).

Impairment of relaxation could potentially involve alterations at any one or more steps in the relaxation pathway (30). Our finding that airway relaxation mediated by both loop diuretics (ion channel antagonists) and salbutamol (cell-surface receptor agonist) was decreased by in vivo exposure to hyperoxia, suggests that hyperoxia mediated effects on the airways may interfere with a more distal (intracellular) step in the

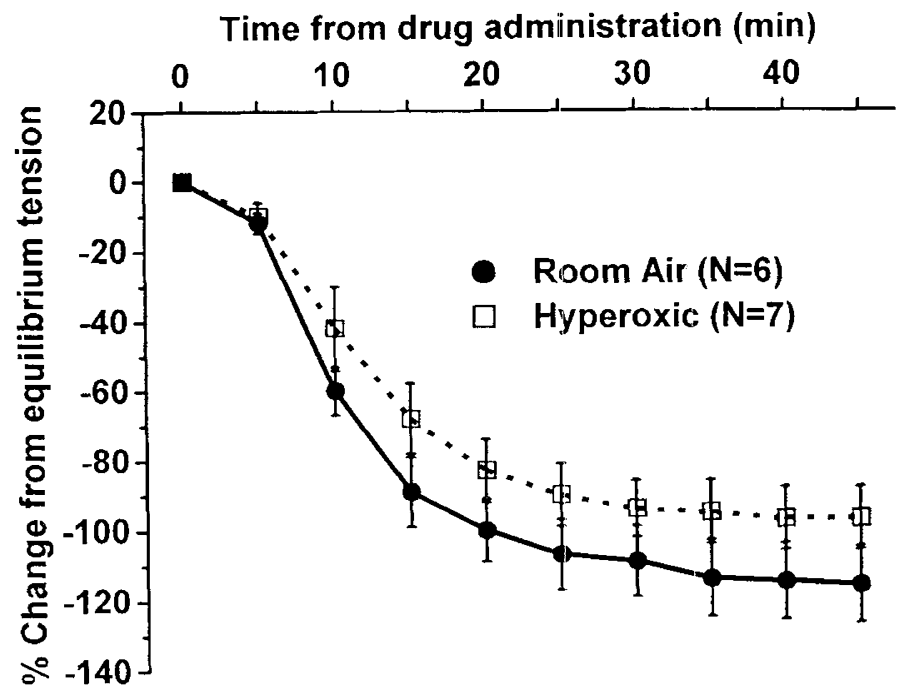

Figure 4. Guinea pig bronchial relaxation response to $3 \times 10^{-6} \mathrm{M}$ ethacrynic acid. In contrast to Figures $1-3$, bronchial relaxation to ethacrynic acid was unchanged by hyperoxia. $n=$ number of animals. Values are mean $\pm \mathrm{SEM}$.

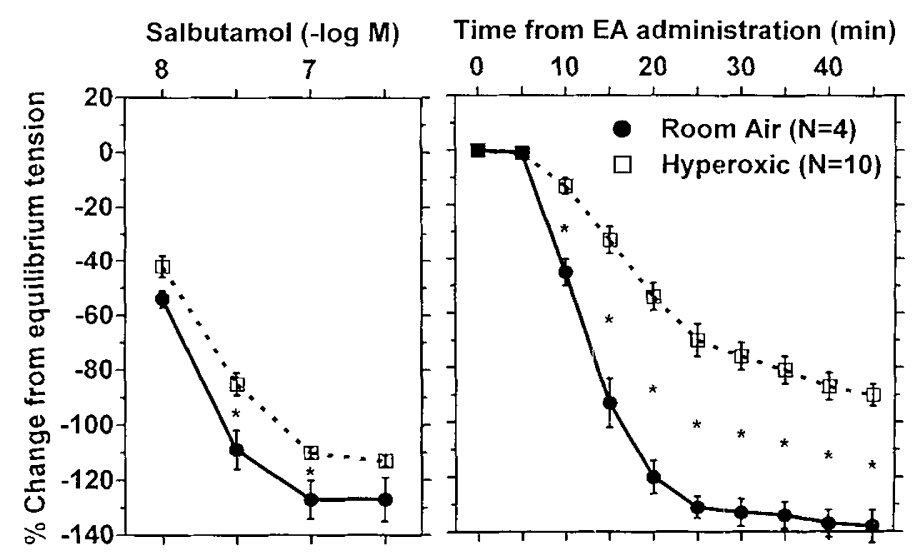

Figure 5. Guinea pig tracheal relaxation response to cumulative doses of $10^{-8}$ to $10^{-6} \mathrm{M}$ salbutamol (left panel) and single dose $3 \times 10^{-6} \mathrm{M}$ ethacrynic acid (right panel). Relaxing efficacy of salbutamol and ethacrynic acid were both decreased in tracheal rings from hyperoxic exposed animals. $n=$ number of animals. Values are mean \pm SEM. ${ }^{*} p<0.05$.

relaxation mechanism. On the other hand, Hershenson et al. (21) recently found that an epithelium-derived constrictor prostaglandin(s) contributes to the observed increase in maximal contractile responsiveness in young rats exposed to hyperoxia. Although we did not specifically address the contribution of an intact epithelium to impaired relaxation herein, future studies may show that epithelium-dependent factors may also have a nonselective effect on relaxation mechanisms.

In addition to the direct effects of hyperoxia on the airway, systemic factors could have played a role in the attenuation of airway relaxation. For example, inasmuch as guinea pigs exposed to hyperoxia demonstrated decreased weight gain, pulmonary growth and therefore function could have been affected. Although we cannot confirm this possibility, the notion is consistent with the findings of Kelly et al. (31) who demonstrated significantly decreased pulmonary protein accretion in undernourished preterm guinea pigs when compared with controls. Despite our incomplete understanding of this possible 

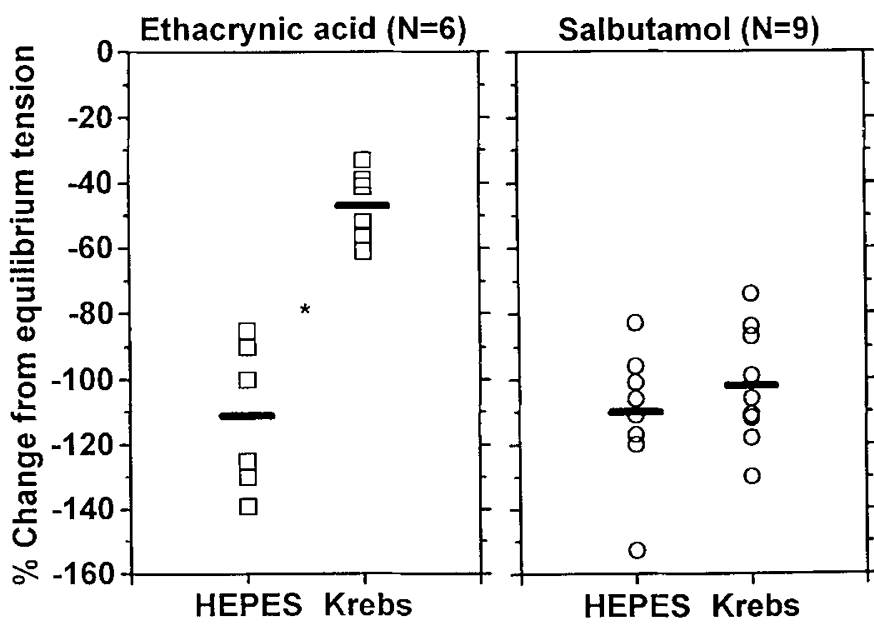

Figure 6. Maximum relaxation of guinea pig tracheal rings in response to 3 $\times 10^{-6} \mathrm{M}$ ethacrynic acid (left panel) and $10^{-7} \mathrm{M}$ salbutamol (right panel) in HEPES vs Krebs buffer. HEPES buffer dramatically augmented the relaxing effect of $3 \times 10^{-6} \mathrm{M}$ ethacrynic acid on normal guinea pig tracheal rings when compared with Krebs. No such difference is demonstrated with $10^{-7} \mathrm{M}$ salbutamol. $n=$ number of animals. ${ }^{*} p<0.05$

relation, these issues remain clinically relevant as newborns exposed to high levels of supplemental oxygen are often poorly nourished.

The relaxing efficacy of ethacrynic acid on large airways was greatly enhanced in HEPES buffer, consistent with our previous work with furosemide (15) and the results of Deth et al. (19) in studies of rat aorta. Based on their detailed studies, Deth $e t$ al. (19) hypothesize that the increase in furosemide effect may be due to enhanced $\mathrm{Na}^{+}-\mathrm{K}^{+}-\mathrm{Cl}^{-}$cotransporter activity in HEPES buffer. The observation that HEPES buffer accentuated loop diuretic-mediated relaxation but did not alter relaxation induced by salbutamol suggests that loop diuretics and $\beta_{2}$-adrenergic receptor agonists may cause relaxation via different pathways. The marked difference in the time course of relaxation between these drugs further supports this hypothesis (32). Additional observations herein and in a previous study (15), that loop diuretics are more effective in relaxing guinea pig airway as opposed to vascular smooth muscle, suggest that differences in cation transport may exist between smooth muscle types. Further studies are necessary to determine whether monovalent cation transport in airway smooth muscle follows similar patterns to those described in vascular smooth muscle.

The observation that ethacrynic acid had similar relaxing properties to furosemide is not as predictable as it might first appear. Although furosemide, bumetanide, and ethacrynic acid are known to exert their action in many tissues by binding to a $\mathrm{Na}^{+}-\mathrm{K}^{+}-\mathrm{Cl}^{-}$cotransporter, furosemide and bumetanide are loop diuretics of the sulfamoylbenzoic acid class, whereas ethacrynic acid is a structurally unrelated dichlorophenoxyacetic acid derivative (18). Ethacrynic acid is a strong alkylating agent which is quickly transformed to ethacrynic acid-Lcysteine and other adducts upon administration (16) Ethacrynic acid-L-cysteine is believed to be the most biologically active form of ethacrynic acid, having a potency 100 times that of ethacrynic acid in the thick ascending loop of Henle (16). Palfrey and Leung (18) found that, in avian eryth- rocytes, the mechanism of action of ethacrynic acid-L-cysteine is distinct from that of ethacrynic acid, and that the cysteine adduct may bind to a different site than bumetanide on the $\mathrm{Na}^{+}-\mathrm{K}^{+}-\mathrm{Cl}^{-}$cotransporter. Ethacrynic acid and furosemide have other characteristics which are unique to each agent $(16$, 17), and ethacrynic acid can produce biologic effects independent of $\mathrm{Na}^{+}-\mathrm{K}^{+}-\mathrm{Cl}^{-}$cotransport $(16,17)$. It should be noted that many in vitro effects of ethacrynic acid are elicited only by higher concentrations of drug (16) than used herein. Taken together, the observation that ethacrynic acid can produce in vitro airway relaxation in the micromolar range provides further support for an extrarenal effect of dichlorophenoxyacetic acid derivatives.

In summary, 1) ethacrynic acid, like furosemide, relaxed normal newborn guinea pig airways; 2) the relaxing effect of furosemide, ethacrynic acid, and salbutamol was decreased in airways from animals exposed to hyperoxia; and 3) loop diuretic-mediated airway relaxation was accentuated in HEPES buffer when compared with Krebs, whereas salbutamolmediated relaxation was unaffected by buffer choice. These results suggest that hyperoxic exposure may nonspecifically decrease airway reactivity to the agents studied.

Acknowledgments. The authors acknowledge the expert technical assistance of Naomi Fujiwara, the advice of Drs. Carol Eisenhauer, David Easa, and Catherine FT Uyehara, and the help of the Department of Respiratory Care, Kapiolani Medical Center for Women and Children.

\section{REFERENCES}

1. Bianco S, Vaghi A, Robuschi M, Pasargiklian M 1988 Prevention of exercise-induced bronchoconstriction by inhaled frusemide. Lancet 2:252-255

2. Bianco S, Pieroni MG, Refini RM, Rottoli L, Sestini P 1989 Protective effect of inhaled furosemide on allergen-induced early and late asthmatic reactions. $N$ Engl J Med 321:1069-1073

3. O'Donnell WJ, Rosenberg M, Niven RW, Drazen JM, Isracl E 1992 Acetazolamide and furosemide attenuate asthma induced by hyperventilation of cold, dry air. Am Rev Respir Dis 146:1518-1523

4. Moscato G, Dellabianca A, Falagiani P, Mistrcllo G, Rossi G, Rampulla C 1991 Inhaled furosemide prevents both the bronchoconstriction and the increase in neutrophil chemotactic activity induced by ultrasonic "fog" of distilled water in asthmatics. Am Rev Respir Dis 143:561-566

5. Seidenberg J, Dehning J, von der Hardt H 1992 Inhaled frusemide against cold ai induced bronchoconstriction in asthmatic children. Arch Dis Child 67:214-217

6. Rush MG, Engelhardt B, Parker RA, Hazinski TA 1990 Double-blind, placebocontrolled trial of alternate-day furosemide therapy in infants with chronic bronchopulmonary dysplasia. J Pediatr 117:112-118

7. Najak ZD, Harris EM, Lazzara A, Pruitt AW 1983 Pulmonary effects of furosemide in preterm infants with lung diseasc. J Pediatr 102:758-763

8. Patel H, Yeh T-F, Jain R, Pildes R 1985 Pulmonary and renal responses to furosemide in infants with stage III-IV bronchopulmonary dysplasia. Am J Dis Child 139:917 919

9. McCann EM, Lewis K, Deming DD, Donovan MJ, Brady JP 1985 Controlled trial of furosemide therapy in infants with chronic lung disease. J Pediatr 106:957-962

10. Engelhardt B, Elliott S, Hazinski TA 1986 Short- and long-term effects of furosemide on lung function in infants with bronchopulmonary dysplasia. J Pediatr 109:1034 1039

11. Elwood W, Loetvall JO, Barnes PJ, Chung KF 1991 Loop diuretics inhibit cholinergic and noncholinergic nerves in guinea pig airways. Am Rev Respir Dis 143:134()-1344

12. Demling RH, Will JA 1978 The effect of furosemide on the pulmonary transvascular fluid filtration rate. Crit Care Med 6:317-319

13. McCaffery C, Levy M 1980 Effect of furosemide on thoracic duct lymph flow in the dog. Am J Physiol 238:363-371

14. Bland RD, McMillan DD, Bressack MA 1978 Decreased pulmonary transvascula fluid filtration in awake newborn lambs after intravenous furosemide. J Clin Invest 62:601-609

15. Stevens EL, Uyehara CFT, Southgate WM, Nakamura KT 1992 Furoscmide differentially relaxes airway and vascular smooth muscle in fetal, newborn, and adul guinea pigs. Am Rev Respir Dis 146:1192-1197

16. Burg MB 1976 Tubular chloride transport and the mode of action of some diuretics. Kidney Int 9:189-197 
17. Bentler JJ, Boer WH, Koomans HA, Mees EJD 1992 Comparative study of the effects of furosemide, ethacrynic acid, and bumetanide on the lithium clearance and diluting segment reabsorption in humans. J Pharmacol Exp Ther 260:768-772

18. Palfrey HC, Leung $\mathrm{S} 1993$ Inhibition of $\mathrm{Na}-\mathrm{K}-2 \mathrm{Cl}$ cotransport and bumetanide binding by ethacrynic acid, its analogues, and adducts. Am J Physiol 264:C1270$\mathrm{C} 1277$

19. Deth RC, Payne RA, Peecher DM 1987 Influence of furosemide on rubidium-86 uptake and $\alpha$-adrenergic responsiveness of arterial smooth muscle. Blood Vessels 24:321-333

20. Uyehara CFT, Pichoff BE, Sim HH, Uemura HS, Nakamura KT 1993 Hyperoxic exposure enhances airway reactivity of newborn guinea pigs. J Appl Physiol $74: 2649-2654$

21. Hershenson MB, Garland A, Kelleher M.D., Zimmerman A, Hernandez C, Solway J 1992 Hyperoxia-induced airway remodeling in immature rats: Correlation with airway responsiveness. Am Rev Respir Dís 146:1294-1300

22. Hershenson MB, Wylam ME, Punjabi N, Umans JG, Schumacker PT, Mitchell RW, Solway J 1994 Exposure of immature rats to hyperoxia increases tracheal smooth muscle stress generation in vitro. I Appl Physiol 76:743-749

23. Northway WH, Rosan RC, Shahinian L, Castellino RA, Gyepes MT, Durbridge T 1969 Radiologic and histologic investigation of pulmonary oxygen toxicity in newborn guinea pigs. Invest Radiol 3:149-155

24. Frank L, Bucher JR, Roberts RJ 1978 Oxygen toxicity in neonatal and adult animals of various species. J Appl Physiol 45:699-704
25. Southgate WM, Pichoff BE, Stevens EL, Balaraman V, Uyehara CFT, Nakamura KT 1993 Ontogeny of epithelial modulation of airway smooth muscle function in the guinea pig. Pediatr Pulmonol 15:105-110

26. Zar JH 1984 Biostatistical Analysis, 2nd Ed. Prentice-Hall, Englewood Cliffs, NJ, pp $150-156,206-233$

27. Frank L 1991 Developmental aspects of experimental pulmonary oxygen toxicity. Free Radical Biol Med 11:463-494

28. Szarek JL 1989 In vivo exposure to hyperoxia increases airway responsiveness in rats. Am Rev Respir Dis 140:942-947

29. Villanove X, Marthan R, Tunon de Lara J, Johnson PRA, Savineau JP, McKay KO Alouan LA, Armour CL, Black JL 1993 Sensitization decreases relaxation in human isolated airways. Am Rev Respir Dis 148:107-112

30. Schramm CM, Grunstein MM 1992 Assessment of signal transduction mechanisms regulating airway smooth muscle contractility. Am J Physiol 262:L119-L139

31. Kelly FJ, Fussell JC, Postle TD 1992 Effect of food restriction on pulmonary growth and protein turnover in preterm guinea pigs. Am J Physiol 262:E240-E245

32. Wiener HL, Murray JM, Thalody GP, Maayani S 1992 Kinetics of relaxation responses to vasorelaxants in isolated rabbit aorta. Eur J Pharmacol 220:131-149

33. Park CS, Doh PS, Carraway RE, Chung GG, Fray JCS, Miller TB 1990 Stimulation of renin secretion by ethacrynic acid is independent of $\mathrm{Na}-\mathrm{K}-2 \mathrm{Cl}$ cotransport. Am J Physiol 1.990 259:F539-F544 